\title{
$\mathrm{Al}$ 合金基複合材料のフレッティング疲労強度に おける第 2 相の役割
}

\author{
角田方衛 丸山典夫 中沢興三
}

\author{
科学技術庁金属材料技術研究所
}

J. Japan Inst. Metals, Vol. 57, No. 10 (1993), pp. 1141-1148

\section{Role of Second Phase in Fretting Fatigue Strength in a SiC-Whisker-Reinforced Aluminum Alloy Composite}

\author{
Masae Sumita, Norio Maruyama and Kouzou Nakazawa
}

Science and Technology Agency, National Research Institute for Metals, Tsukuba

The fretting fatigue strength at $10^{7}$ cycles was $106 \mathrm{MPa}$ in the $\mathrm{SiC}_{\mathrm{w}} / 7075-\mathrm{T} 6 \mathrm{Al}$ composite, and $62 \mathrm{MPa}$ in the 7075-T6 alloy. The fatigue strength at $10^{7}$ cycles was $155 \mathrm{MPa}$ in both the materials.

A method to evaluate the role of reinforcement phase in fatigue strength and fretting fatigue strength in a metal matrix composite was proposed, which distinguish the increase in the fatigue and fretting fatigue strengths due to the increase in ulutimate tensile strength by reinforcement from the increase in the strengths of the com. posite materials.

The results of the evaluation of the fretting fatigue strength at $10^{7}$ cycles in the $\mathrm{SiC}_{\mathrm{w}} / 7075-\mathrm{T} 6$ alloy composite on the basis of the above method was that the gross increase was $44 \mathrm{MPa}(70 \%)$ and the net increase was 38 $\mathrm{MPa}(57 \%)$ in the strength due to the reinforcement, compared with the strength in the 7075-T6 alloy. It seems that the net increase in the strength in the composite is owing to the low stress concentration in the fretted area and the restriction of crack initiation by reinforcement.

The practical value of the fatigue strength at $10^{7}$ cycles in the $\mathrm{SiC}_{\mathrm{w}} / 7075-\mathrm{T} 6$ alloy composite is nearly equal to the estimated value. The crack was initiated from the defect whose size was $150 \sim 200 \mu \mathrm{m}$.

The effects of $\mathrm{SiC}$ wisker reinforcement on the friction coefficient, main crack initiation site on the fretted area, paring off of microcracks by pad, crack initiation, and crack propagation in the composite materials were discussed.

(Received April 22, 1993)

Keywords: metal matrix composite, fatigue, fretting fatigue, strength evaluation, role of reinforcement phase

\section{I．緒言}

金属基複合材料(以後複合材料と呼ぶ)は，マトリックスの材 料(以後非強化材料之呼ぶ) 飞比べて，延性や勒性は犠牲にする が，高比強度，高此弾性である．強化材の種類によっては従来 の治金学的プロセッシングがそのま適用でき，加工も可能で ある、複合材料は上記の特性を生かして，航空機，自動車など の将来の構造物用材料として期待されている(1).

複合材料が使用される構造物には疲労荷重やフレッティング 疲労荷重が加わる可能性が高い，複合材料は，非強化材料に比 ベて優れた摩耗特性を有するので(2)(3)，特にフレッティング疲 労が問題になるような構造物用材料として有望と考党られる。 したがって，複合材料の疲労特性括よびフレッティング疲労特 性を解析して十分に理解し，それらの強度向上の可能性につい て考えることは重要である。

これすで複合材料の疲労強度特珄に関する研究は多数行わ れている，複合化によりナング率(以後 $E$ と記す)や引張強度
(以後 $\sigma_{\mathrm{B}}$ と記す)が増加すれば，去の分疲労強度る增加する がここれらの問題を論じた報告は㾏とんど見られない(4).一 方，複合材料のフレッティング疲労に関する研究はほとんどな い.

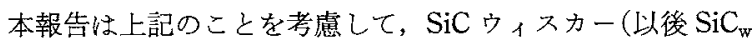
と呼ぶ)で強化した 7075-T6 Al 合金を用いて，複合化による フレッティング疲労強度向上について，Eの寄与分， $\sigma_{\mathrm{B}}$ の奇 与分それに強化相による強化機構発現に上る寄与分を分けて考 察した. 去して $\mathrm{SiC}_{\mathrm{w}}$ がフレッティング疲労強度向上に強化相 として有效であることを示した。

\section{II. 実 験 方 法}

\section{1. 対象材料}

直径 $0.1 \sim 1 \mu \mathrm{m}$, 長さ $5 \sim 50 \mu \mathrm{m} の \mathrm{SiC}_{\mathrm{w}}$ と7075Al 合金粉末 とを溶媒中で分散, 混合した後, 溶媒を除去して得られた混合 粉末を高温高圧下で固化成形し，それを押出し加工により 25 mmoの丸棒とし， T6 処理を施した素材を用いた． $\mathrm{SiC}_{\mathrm{w}}$ の体積 
Table 1 Mechanical Properties of materials used.

\begin{tabular}{l|c|c|c|c|c|c}
\hline \hline & $\begin{array}{c}\mathrm{SiC}_{\mathrm{w}} \text { volume } \\
(\%)\end{array}$ & $\begin{array}{c}\sigma_{0.2} \\
(\mathrm{MPa})\end{array}$ & $\begin{array}{c}\sigma_{\mathrm{B}} \\
(\mathrm{MPa})\end{array}$ & $\begin{array}{c}\delta \\
(\%)\end{array}$ & $\mathrm{Hv}$ & $\begin{array}{c}E \\
(\mathrm{MPa})\end{array}$ \\
\hline 7075-T6 FRM & 20 & 660 & 758 & 1.3 & 230 & 120000 \\
7075-T6 & - & 689 & 702 & 6.7 & 200 & 70600 \\
\hline
\end{tabular}

率は20\%である． $\mathrm{SiC}_{\mathrm{w}} / 7075-\mathrm{T} 6$ 複合材料と比較のため基準と なる材料として用いた 7075-T6 合金の力学的性質を Table 1 に示す．複合材料の L 方向(押出し力向) 执よび $\mathrm{T}$ 方向(押出し 方向に直角方向)の SEM 写真を Fig. 1(a)おょよび(b)に示す. ウィスカーは押出し方向に優先的K配向している. SEM 写真 上のウィスカー長さは $1 \sim 5 \mu \mathrm{m} の$ のが多く，ウィスカーは 押出し時に破断している。本材料でパッドと試験片は作製され た。

\section{2. 試験方法}

フレッティング疲労試験片，パッドの形状括よびフレッティ ング疲労試験模式図をFig. 2(a)，(b) 括よび(c)に示す、試験 は土10 $\mathrm{t}$ 電気油圧型疲労試験機を用いた。フレッティング疲労 試験は, 試験片の平行部の両側面にブリッジ型のパッドを一定 の力で押付けた状態で，試験片に繰返し荷重を加兄る方法を用 いた。パッド押付け力は試験機本体油圧源から分吱した油圧を 利用して小型アクチュエータにより付与した、フレッティング 疲労試験の詳細は別報(5) と同様である. 試験片表面拉よびパッ ド接触面は 0 番エメリ一紙で研磨した後アセトンで脱脂した。

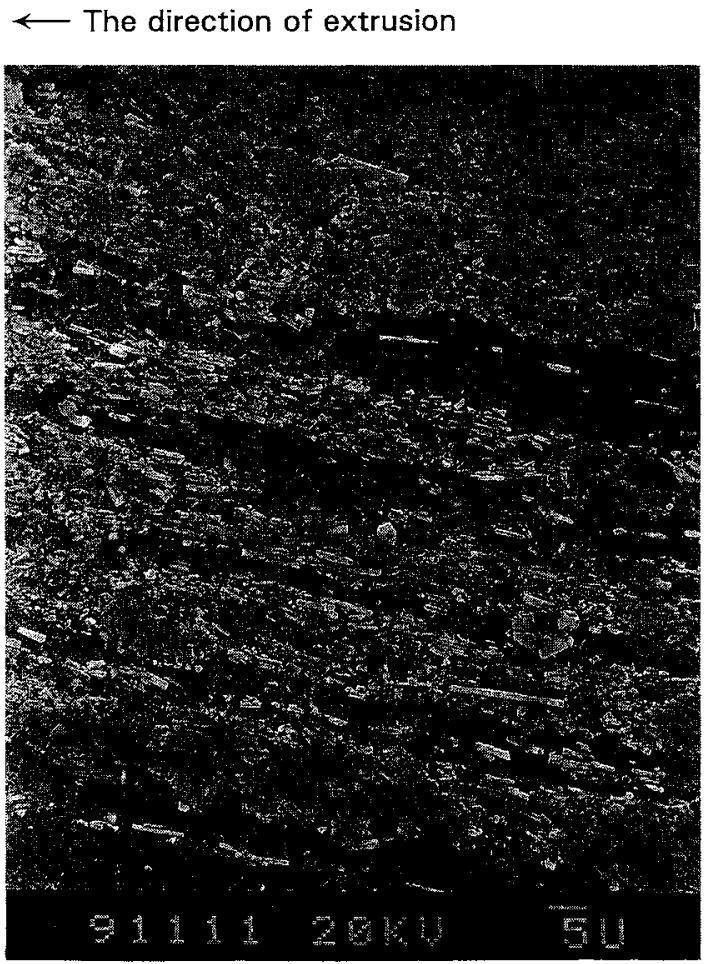

(a) (a)

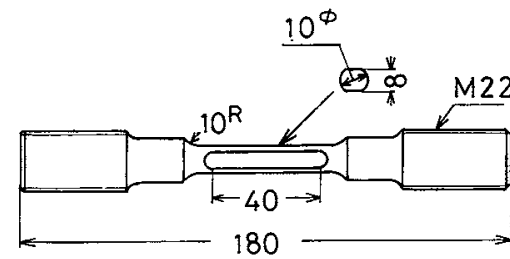

(b)
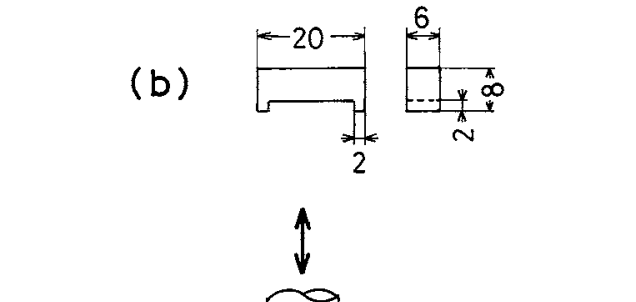

(c)

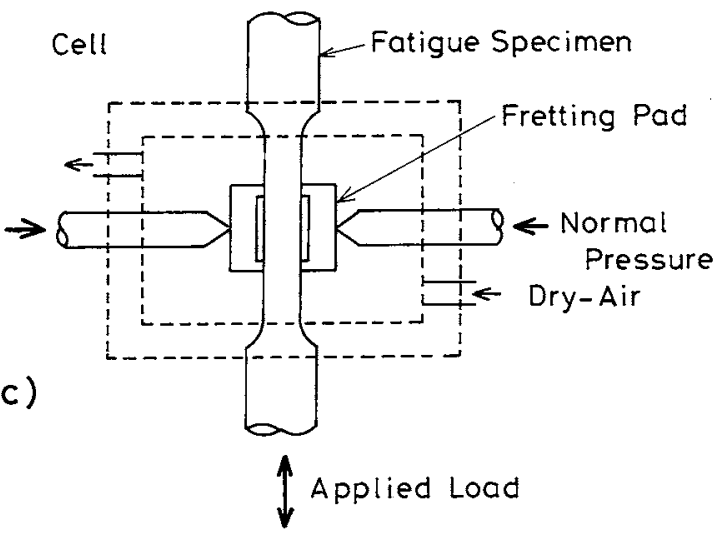

Fig. 2 Dimensions of a fretting fatigue specimen (a), a pad (b) and schematic representation of fretting fatigue test (c).

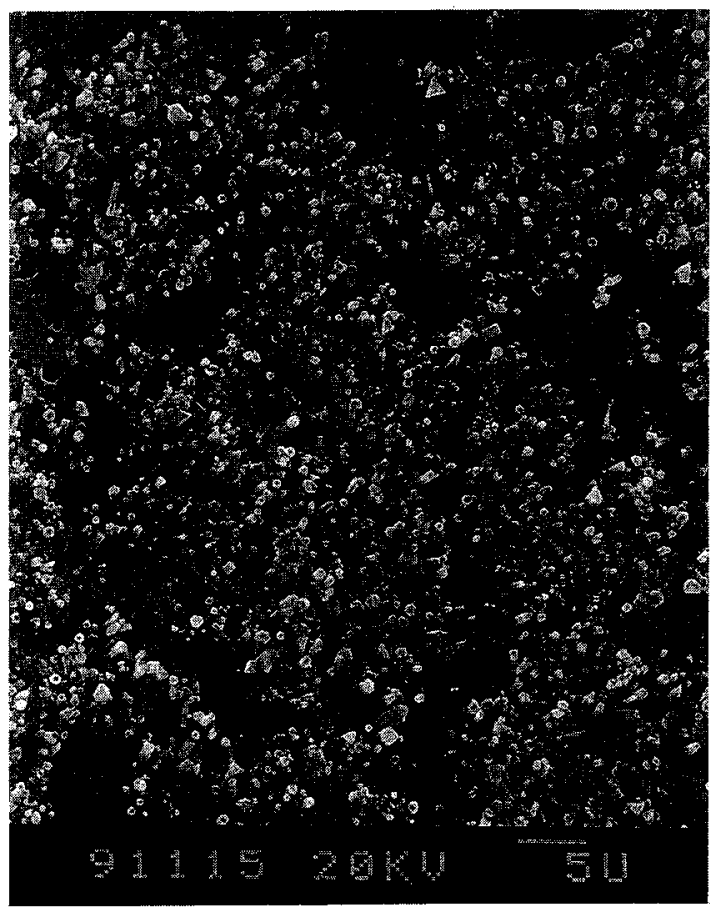

(b)

Fig. 1 SEM photographs of 20 volume $\% \mathrm{SiC}_{\mathrm{w}} / 7075-\mathrm{T} 6 \mathrm{Al}$ composite.

(a) L-direction. (b) T-direction. 
試験中に特けるパッドと試験片間の摩擦力はパッド中心部側面 に貼ったひずみゲージより求めた。

試験は応力比 0.1 軸荷重下で, 繰返し速度 $20 \mathrm{~Hz}$ で, 応力 波形はサイン波で, そしてパッド接触面圧は $50 \mathrm{MPa}$ で行っ た. 試験環境は相対湿度 $0.5 \%$ 以下の室温大気中で行った. 破 面およびフレッティング表面観察には走査型電子顕微鏡を用い た。

\section{III. 結 果}

\section{1. 疲労強度およびフレッティング疲労強度}

$\mathrm{SiC}_{\mathrm{w}} / 7075-\mathrm{T} 6$ 複合材料と 7075-T6 合金の通常疲労の S-N 曲線拈よびフレッティング疲労の S-N 曲線を Fig. 3 亿示す. 同図から次のことが分かる.

（a）複合材料の通常疲労寿命は非強化材料の寿命に比べて約 1 析長い. しかし $10^{7}$ 回通常疲労強度は複合材料扣よび非強化 材料ともに約 $155 \mathrm{MPa}$ であり, 両者間で差はほとんどみられ ない。

(b) 複合材料の $10^{7}$ 回フレッティング疲労強度は $106 \mathrm{MPa}$

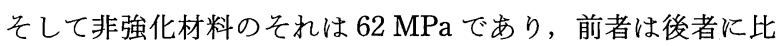
べて約70\%高い.S-N 曲線の傾斜部に扮いて複合材料の寿命 は非強化材料の寿命より長いが，それは高サイクル側ほど顕著 である。

\section{2. パッド接触部の主き裂発生位置}

Fig. 3 に执いて非強化材料のフレッティング疲労で破断した 7 本の試験片のらち $\sigma_{\mathrm{a}}$ が $60 \sim 130 \mathrm{MPa}$ の 6 本はパッド接触部 中央でき裂は発生している. 一方, 複合材料の場合, $\sigma_{\mathrm{a}}=150$ $\mathrm{MPa}$ ではき裂はパッド接触部中央部で発生しているが，他は すべて接触部端部から発生している.

3. 中断フレッティング疲労寿命

疲労寿命に扣よぼすフレッティング損傷の影響を調べるため

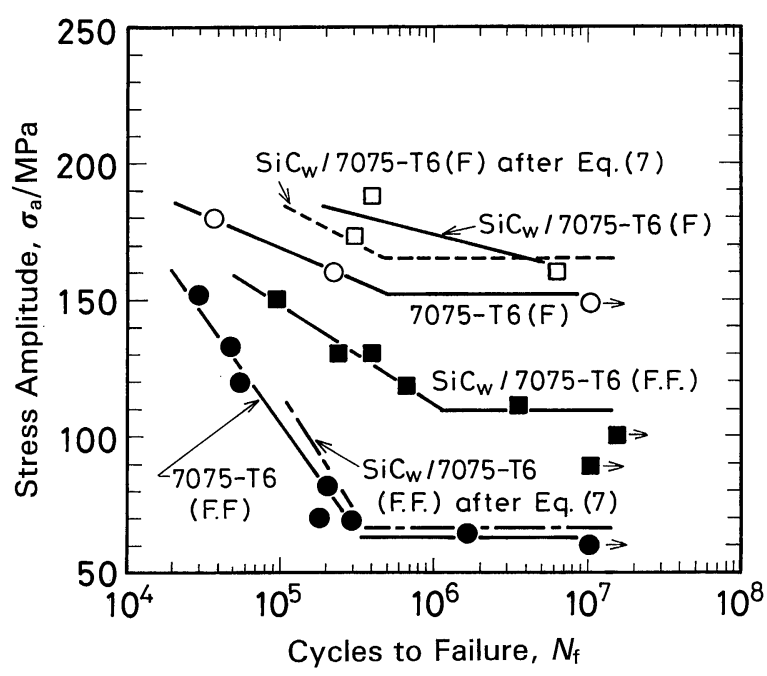

Fig. 3 Fatigue and fretting fatigue behavior of a $\mathrm{SiC}_{\mathrm{w}} /$ $7075 \mathrm{Al}$ alloy composite and a $7075 \mathrm{Al}$ alloy. (F.: Fatigue, F.F.: Fretting fatigue)
に, ある繰返し数だけフレッティング疲労試験をした後, フレ ッティング用パッドを取り外し, 引き続き同一応力振幅で通常 の疲労試験に移行する寿命試験を行った. 非強化材料に関して は, 応力振幅 $\sigma_{\mathrm{a}}$ は $69 \mathrm{MPa}$ 扣よび $133 \mathrm{MPa}$ の 2 水準で, そ して複合材料に関しては $132 \mathrm{MPa}$ の 1 水準で試験を行った. 非強化材料の結果を Fig. 4(a) に，そして複合材料の結果を Fig. 4(b) 飞示す. 縦軸はフレッティング疲労繰返し数にその 後移行した通常疲労繰返し数を加えた繰返し数 $\left(N_{\mathrm{t}}\right)$, そして 横軸はフレッティング疲労繰返し数 $\left(N_{\mathrm{f}}\right)$ である. $N_{\mathrm{t}}=N_{\mathrm{f}}$ の線 上の值はフレッティング疲労試験結果を示す．この試験条件下 では通常疲労の寿命は $10^{7}$ 回以上である. 一方, フレッティン グ疲労寿命は非強化材料に执いて $\sigma_{\mathrm{a}}=69 \mathrm{MPa}$ では約 $3 \times 10^{5}$ 回, $\sigma_{\mathrm{a}}=133 \mathrm{MPa}$ では約 $5 \times 10^{4}$ 回である. そして複合材料に 括いては $\sigma_{\mathrm{a}}=132 \mathrm{MPa}$ で約 $3 \times 10^{5}$ 回である. 非強化材料の $\sigma_{\mathrm{a}}=69 \mathrm{MPa}$ の場合和よび複合材料の $\sigma_{\mathrm{a}}=132 \mathrm{MPa}$ の場合つ レッティング疲労寿命に極めて近い繰返し数でパッドを取り外 し，通常の疲労試験に移行すると $10^{7}$ 回までに破断しない。こ のことはこのフレッティング疲労条件下では試験片の破断直前 まで摩擦力が関与していることを意味している.すなわちフレ ッティング疲労損傷は最終破断近くまで飽和しない.ところ が, 非強化材料の $\sigma_{\mathrm{a}}=133 \mathrm{MPa}$ の場合, フレッティング疲労 繰返し数の中で摩擦力が関与しない繰返し数の割合が増加す
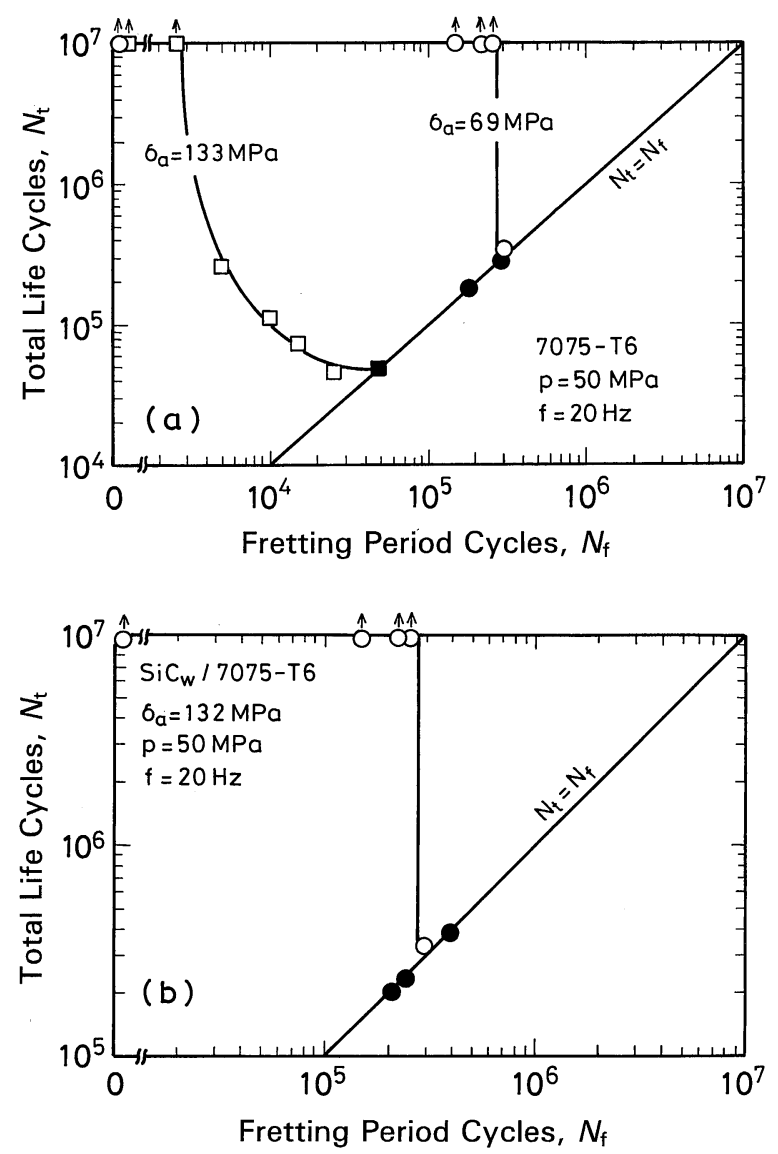

Fig. 4 Effect of fretting period cycles on total life cycles. (a) 7075-T6 Al Alloy.

(b) $\mathrm{SiC}_{\mathrm{w}} / 7075-\mathrm{T} 6$ composite. 
る. 例总ば， $10^{4}$ 回のフレッティング疲労繰返し数後通常疲労 に移行したときの全寿命は約 $10^{5}$ 回であり，全寿命の初期段階 の約 $10 \%$ 摩擦力が関係し，残りの90\%は通常疲労によるも のである.そしてフレッティング損傷はフレッティング疲労寿

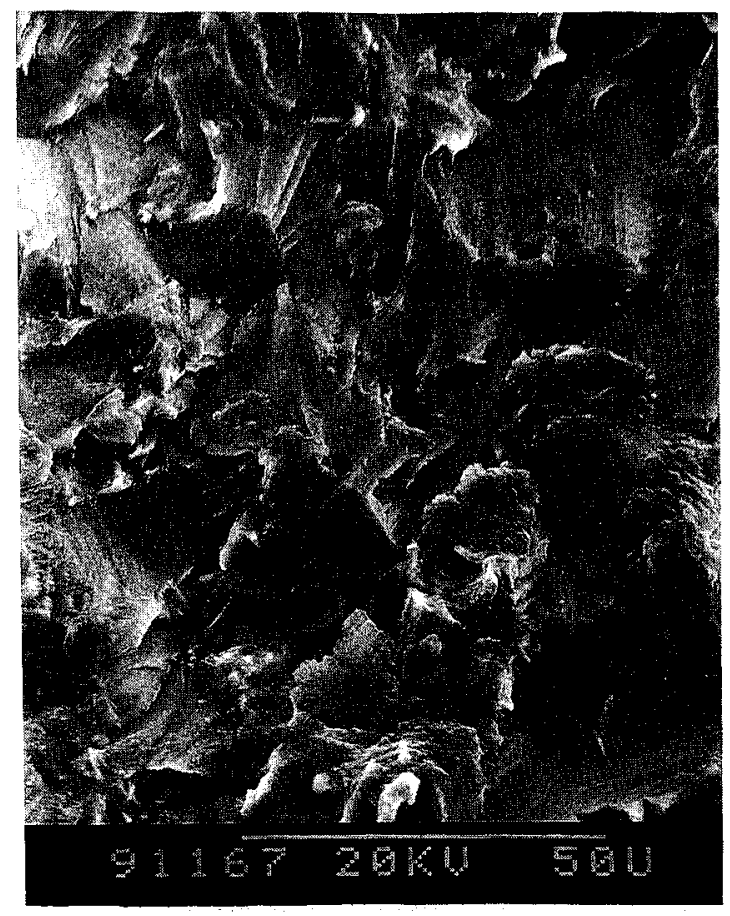

(a)
命の約 $50 \%$ で飽和する。

\section{4. 破面観察}

通常疲労破面括よびフレッティング疲労破面は，非強化材料

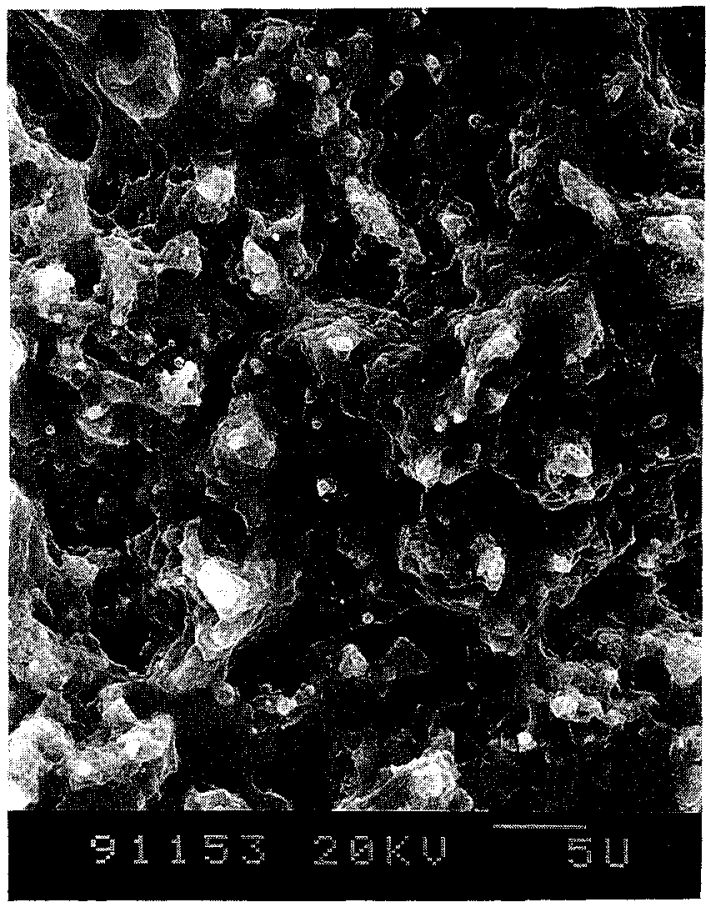

(b)

Fig. 5 Typical crack growth in fretting fatigue.

(a) 7075-T6 Al alloy $\sigma_{\mathrm{a}}=64 \mathrm{MPa}, N_{\mathrm{f}}=1.65 \times 10^{5}$, (b) $\mathrm{SiC}_{\mathrm{w}} / 7075-\mathrm{T} 6 \mathrm{Al}$ composite $\sigma_{\mathrm{a}}=111 \mathrm{MPa}, N_{\mathrm{f}}=3.57 \times 10^{6}$.

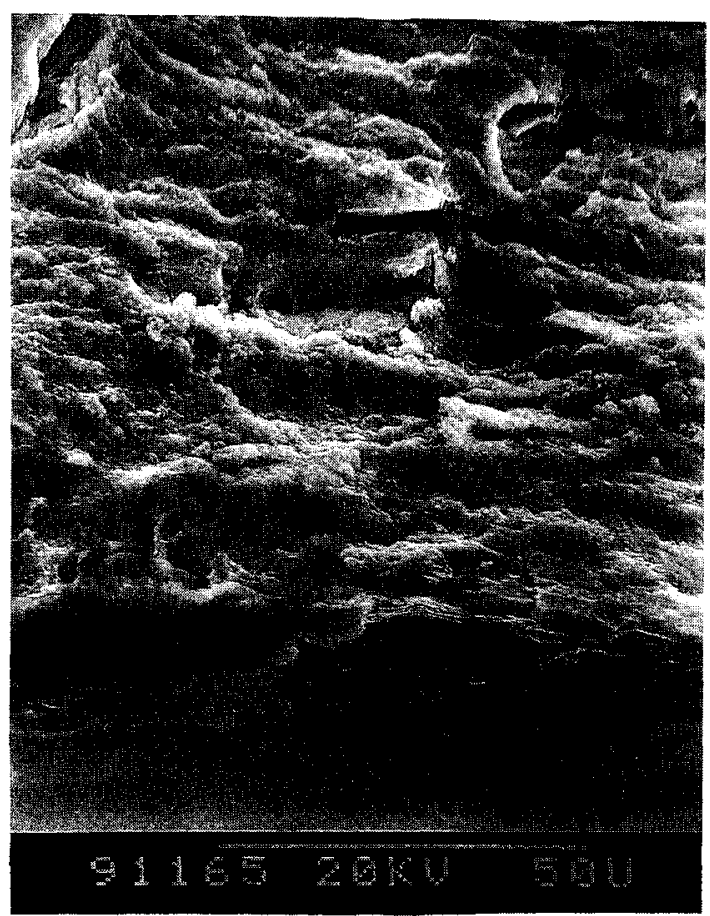

(a)
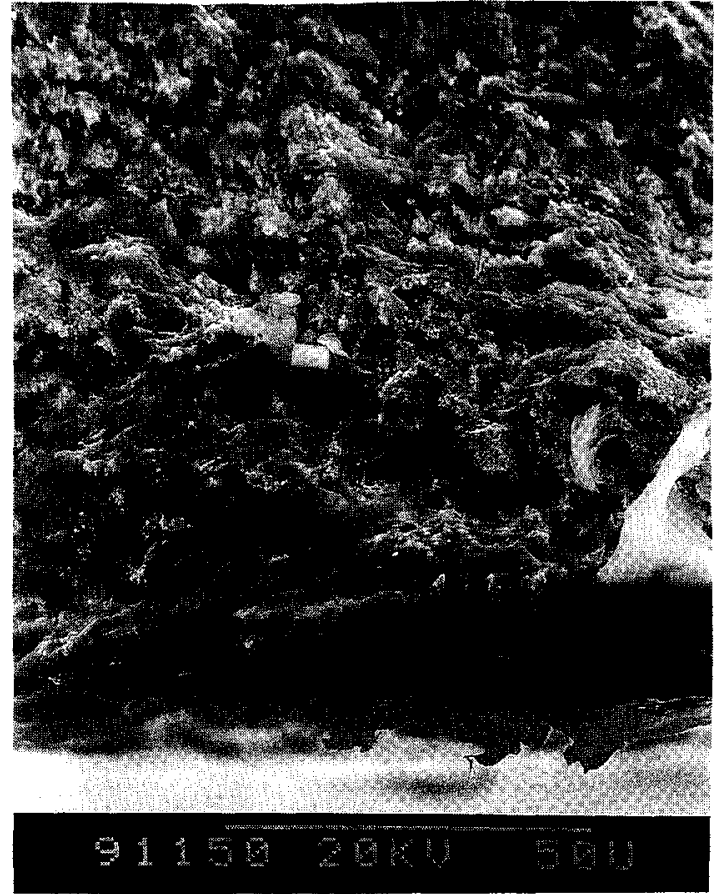

(b)

Fig. 6 Typical crack initiation sites in fretting fatigue.

(a) 7075-T6 Al alloy $\sigma_{\mathrm{a}}=64 \mathrm{MPa}, N_{\mathrm{f}}=1.65 \times 10^{5}$, (b) $\mathrm{SiC}_{\mathrm{w}} / 7075-\mathrm{T} 6 \mathrm{Al}$ composite $\sigma_{\mathrm{a}}=111 \mathrm{MPa}, N_{\mathrm{f}}=3.57 \times 10^{5}$. 
に执いてはFig. 5(a)に示すように, 全般に脆性的なへき開破 面を呈して括り, そして複合材料に括いては, Fig. 5(b)に示 すよらに全般にディンプル破面である．後者の破面上には $\mathrm{SiC}_{\mathrm{w}}$ が抜けた穴あるいは押出し方向に直角方向に配列した $\mathrm{SiC}_{\mathrm{w}}$ が多数観察される. しかし破面上にウィスカーの破片が 散乱している状況は欠陷部以外では観察されない.

フレッティング疲労き裂発生個所の写真を Fig. 6(a) 括よび (b)に示す. この領域では非強化材料扣よび複合材料ともに大 きな塑性変形を伴った延性破面を呈して括り, 破壊様式の両材 料間の大きな相違はみられない。

\section{N. 考察}

\section{1. 疲労強度およびフレッティング疲労強度に対する複合化 効果評価方法の提起}

応力 $\sigma_{\mathrm{c}}$ 下にある複合材料に生じるひずみを $\varepsilon_{\mathrm{c}}$ とすると， 、 トリックス部分には $\varepsilon_{\mathrm{c}}$ に対応する応力 $\sigma_{\mathrm{M}}$ が加わっている. $\sigma_{\mathrm{c}}$ と $\sigma_{\mathrm{M}}$ の間には次の関係が存在する.

$$
\sigma_{\mathrm{c}}=\sigma_{\mathrm{M}} \cdot E_{\mathrm{c}} / E_{\mathrm{M}}
$$

ここで $E_{\mathrm{c}}$ と $E_{\mathrm{M}}$ はそれぞれ複合材料と非強化材料の $E$ であ る. したがって Fig. 7 亿示すよらに疲労強度 $\sigma_{\mathrm{w}, \mathrm{M}}$ を有する 非強化材料を複合化することにより, 式 (2)で求まる疲労強 度 $\sigma_{\mathrm{w}, \mathrm{c}}^{*}$ を有する複合材料が得られたならば，それは複合化に よりEが増加したためであり, 複合化によりマトリックス自 体の疲労強度が増加したためではない。

$$
\sigma_{\mathrm{w}, \mathrm{c}}^{*}=\sigma_{\mathrm{w}, \mathrm{M}} \cdot E_{\mathrm{c}} / E_{\mathrm{M}}
$$

材料の種類が同じ場合, 金属材料に捻いて高サイクル側の $\sigma_{\mathrm{w}, \mathrm{M}}$ は引張強さ $\sigma_{\mathrm{B}}$ に比例する.

$$
\sigma_{\mathrm{w}, \mathrm{M}}=K \cdot \sigma_{\mathrm{B}, \mathrm{M}}
$$

ここで $K$ は定数そして $\sigma_{\mathrm{B}, \mathrm{M}}$ は非強化材料の $\sigma_{\mathrm{B}}$ である. $K$ は 金属材料においては $1 / 2 \sim 1 / 3 て ゙ あ る{ }^{(6)}$.

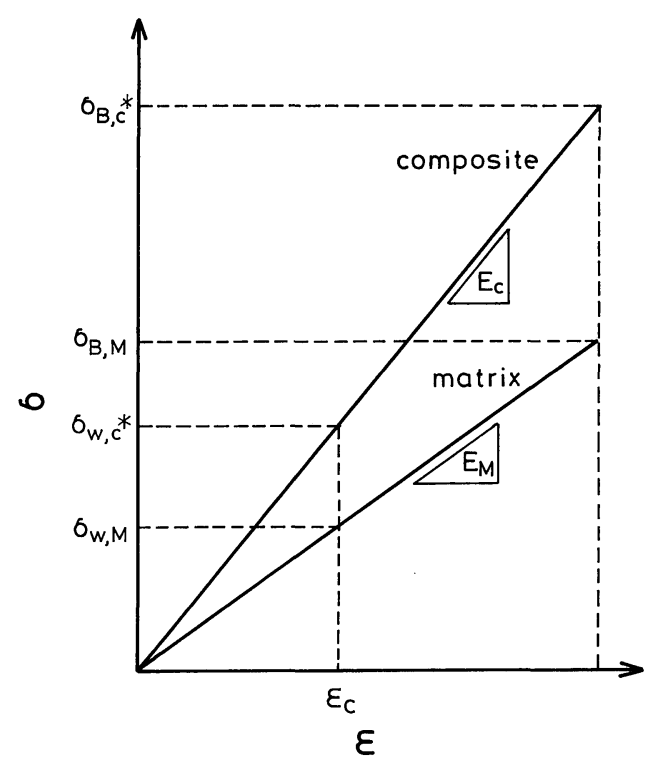

Fig. 7 Schematic representation of stress as a function of strain in matrix and composite to explain eqs. (2), (4) and (5).
金属材料の耐久限度が $\sigma_{\mathrm{B}}$ に比べて著しく低いのは, 疲労に おいては微視組織学的に一番弱い個所に損傷が絽返し集中して き裂が発生し，それが伝播して破壊に至るからである. 金属基 複合材料に括いては金属の特性を生かして, 複合化により力学 特性の強化を計る.したがって複合材料の疲労は金属材料と同 様に繰返し数依存型の破壊である. そこで複合材料に揖いても 金属材料に和将る式 (3) と同じ関係が存在すると仮定する.

$$
\sigma_{\mathrm{w}, \mathrm{c}}^{*}=K \cdot \sigma_{\mathrm{B}, \mathrm{c}}^{*}
$$

ここで $\sigma_{\mathrm{B}, \mathrm{c}}^{*}$ は複合材料の Fig. 7 で定義される $\sigma_{\mathrm{B}}$ である. 式 (2)扣よび (4)より

$$
\sigma_{\mathrm{w}, \mathrm{c}}^{*}=\sigma_{\mathrm{w}, \mathrm{M}} \cdot \sigma_{\mathrm{B}, \mathrm{c}}^{*} / \sigma_{\mathrm{B}, \mathrm{M}}
$$

複合材料の実際の引張強さ $\sigma_{\mathrm{B}, \mathrm{c}}$ が $\sigma_{\mathrm{B}, \mathrm{c}}^{*}$ より小さくなれば, 複合材料の実際の疲労強度 $\sigma_{\mathrm{w}, \mathrm{c}}$ は $\sigma_{\mathrm{w}, \mathrm{c}}^{*}$ より小さくなる.した がってその効果を取り入れた $\sigma_{\mathrm{w}, \mathrm{c}}$ は $\sigma_{\mathrm{w}, \mathrm{c}}^{*}$ に $\sigma_{\mathrm{B}, \mathrm{c}} / \sigma_{\mathrm{B}, \mathrm{c}}^{*}$ を乗じ たものになり，式（５)は次のようになる.

$$
\begin{aligned}
\sigma_{\mathrm{w}, \mathrm{c}} & =\sigma_{\mathrm{w}, \mathrm{c}}^{*} \cdot \sigma_{\mathrm{B}, \mathrm{c}} / \sigma_{\mathrm{B}, \mathrm{c}}^{*} \\
& =\sigma_{\mathrm{w}, \mathrm{M}} \cdot \sigma_{\mathrm{B}, \mathrm{c}}^{*} / \sigma_{\mathrm{B}, \mathrm{M}} \cdot \sigma_{\mathrm{B}, \mathrm{c}} / \sigma_{\mathrm{B}, \mathrm{c}}^{*} \\
& =\sigma_{\mathrm{w}, \mathrm{M}} \cdot \sigma_{\mathrm{B}, \mathrm{c}} / \sigma_{\mathrm{B}, \mathrm{M}}
\end{aligned}
$$

式 $(6)$ は複合化することによる $E$ と $\sigma_{\mathrm{B}}$ の变化を考慮した式で ある. 式(4)を仮定した結果， $\sigma_{\mathrm{w}}$ は $E$ に独立した值となって いる. もし, 複合材料の疲労強度が式 (6) から求まる推定值 より高いならば, 複合化はマトリックス材料の疲労強度向上に 作用したことを意味し，一方実測值が式 (6)の值より低いな らば，複合化は疲労強度に対してマイナスに作用したことを意 味する.

以上の考え方はフレッティング疲労強度に対しても適用でき る.フレッティング疲労に执いてはき裂発生挙動と初期き裂伝 播挙動がパッドと試験片間の摩擦係数, パッド接触部の応力集 中, そしてパッド接触面の摩耗の影響を受ける ${ }^{(7)}$. これらが通 常の疲労と異なる点であるが, 本質的には繰返し応力下で生じ る疲労破壊である.

文献(5)扣よび(8)のデータを整理して鉄鋼材料に関する $10^{7}$ 回フレッティング疲労強度と $\sigma_{\mathrm{B}}$ との関係を求め, それを

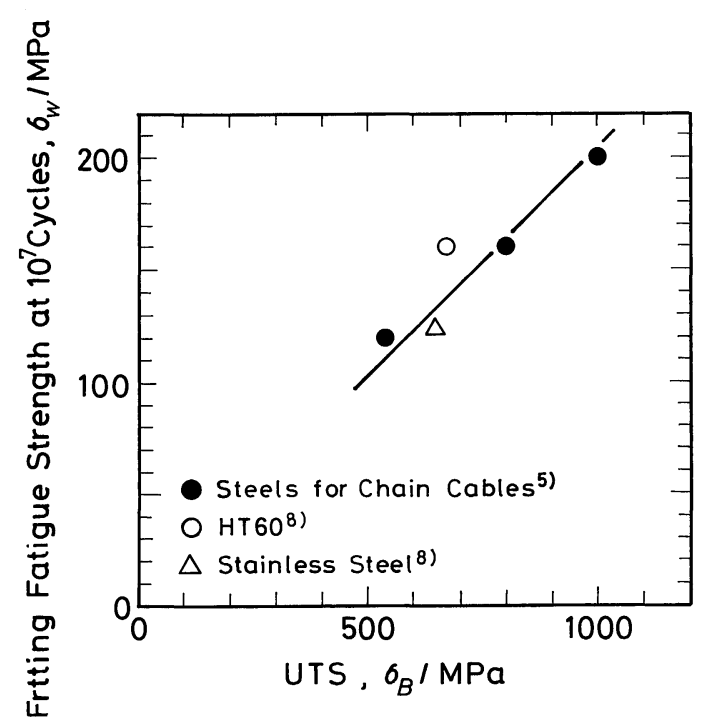

Fig. 8 Fretting fatigue strength as a function of UTS. 
Fig. 8 に示す.フレッティング疲労強度は通常の疲労強度と 同样に $\sigma_{\mathrm{B}}$ にほぼ比例する。な扣，チタン合金に関してはこの ような整理がでさるデータは存在しない。

Table 1 に示したように複合材料の $\sigma_{\mathrm{B}}$ は $758 \mathrm{MPa}$ ，非強化 材料の $\sigma_{\mathrm{B}}$ は $702 \mathrm{MPa}$ であるので，式(6)は次式のようにな る。

$$
\sigma_{\mathrm{w}, \mathrm{c}}=\sigma_{\mathrm{w}, \mathrm{M}} \cdot 758 / 702=1.08 \sigma_{\mathrm{w}, \mathrm{M}}
$$

式(7)を用いた，通常疲労路よびフレッティング疲労の $\sigma_{\mathrm{w}, \mathrm{c}}$ 推定値を Fig. 3 中に点線扣よび一点鎖線で示す.これらの推 定值と複合材料の疲労強度和よびフレッティング疲労強度実湘 值をN.2および 3 で比較検討する。

\section{2. $\mathrm{SiC}_{\mathrm{w}} / 7075-\mathrm{T} 6$ 合金の通常疲労強度実測值と式 $(6)$ に基 づくその推定値との比較}

Fig. 3 に示したように $10^{7}$ 回通常疲労強度の式 $(7)$ そよる複 合材料の推定值は約 $169 \mathrm{MPa}$ ，実測值は約 $160 \mathrm{MPa}$ ，そして 非強化材料の実測值は $155 \mathrm{MPa}$ である。複合材料の $10^{7}$ 回疲 労強度の実測值と推定值の間に汪とんど美がない，

複合材料の疲労き裂発生個所を調べた結果，き裂はすべて大

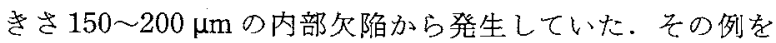
Fig. 9(a) 亿示す。你部には同(b)に示すように $\mathrm{SiC}_{\mathrm{w}}$ が散乱 しているのが観察された。したがって複合材料の疲労強度は， この欠陌による応力集中が原因して低下していると考えられ $3^{(9)(10)}$.

文献(11)によれば，2024-T6 合金和よび $10 \% \mathrm{SiC}_{\mathrm{w}} / 2024-$ T6 合金の $10^{7}$ 回回転曲济疲学強度はそれぞれ $150 \mathrm{MPa}$ 执よ び $250 \mathrm{MPa}$ である. 前述の式(6)を用いて文献(11)の複合材 料の $10^{7}$ 回疲労強度を推定すると約 $200 \mathrm{MPa}$ で炙り，実測值
の方が $25 \%$ 高い

文献(12)飞よれば，6061-T6 合金および $17 \% \mathrm{SiC}_{\mathrm{w}} / 6061$ T6 合金の $10^{7}$ 回回転曲代疲労強度はそれぞれ $95 \mathrm{MPa}$ 就よび $160 \mathrm{MPa}$ である. 前述の式(6)を用いてこの複合材料の $10^{7}$ 回疲労強度を推定すると約 $155 \mathrm{MPa}$ であり，実測值と同じ水 準である。

文献(12)の場合疲労き裂発生個所は不明であるが，本実験 結果から推察すると，き裂は内部尔陷加ら発生している可能性 が高い。すなわち， $\mathrm{SiC}_{\mathrm{w}}$ による強化は，プロセッシングに注 意が払われるならば，通常疲労強度を高める機構を発現させる ことができると考光られる。

3. $\mathrm{SiC}_{\mathrm{w}} / \mathbf{7 0 7 5 - \mathrm { T } 6}$ 合金のフレッティング疲労強度実測值と 式 (6)に基づく推定値との此較

Fig. 3 飞示したように，式(7)による複合材料の $10^{7}$ 回フレ ッティング疲労強度の推定值は $67 \mathrm{MPa}$ であのに対して, 実測值は $106 \mathrm{MPa} て ゙$ 更り，38 $\mathrm{MPa}(57 \%)$ 高くなっている。 このことは $\mathrm{SiC}_{\mathrm{w}}$ による強化は高サイクル側のフレッティング 疲労強度向上に有效であり, 何らかの強化機構が発現している と考光られる。しかし低サイクル側では複合化による效果は滦 とんど見られない、な拉，フレッティング疲労の昜合，き裂は すべてパッド接触部で発生して括り，試験片内部に存在する欠 陷が寿命㶤影響を技よ济す例は存在しなかった。

\section{4. $\mathrm{SiC}_{\mathrm{w}}$ 相のフレッティング疲労強度への影響}

V.3で述べたよらそ $\mathrm{SiC}_{\mathrm{w}}$ は高サイクル域でのフレッティン グ疲労強度向上飞有效であった，先の中味について検討する。
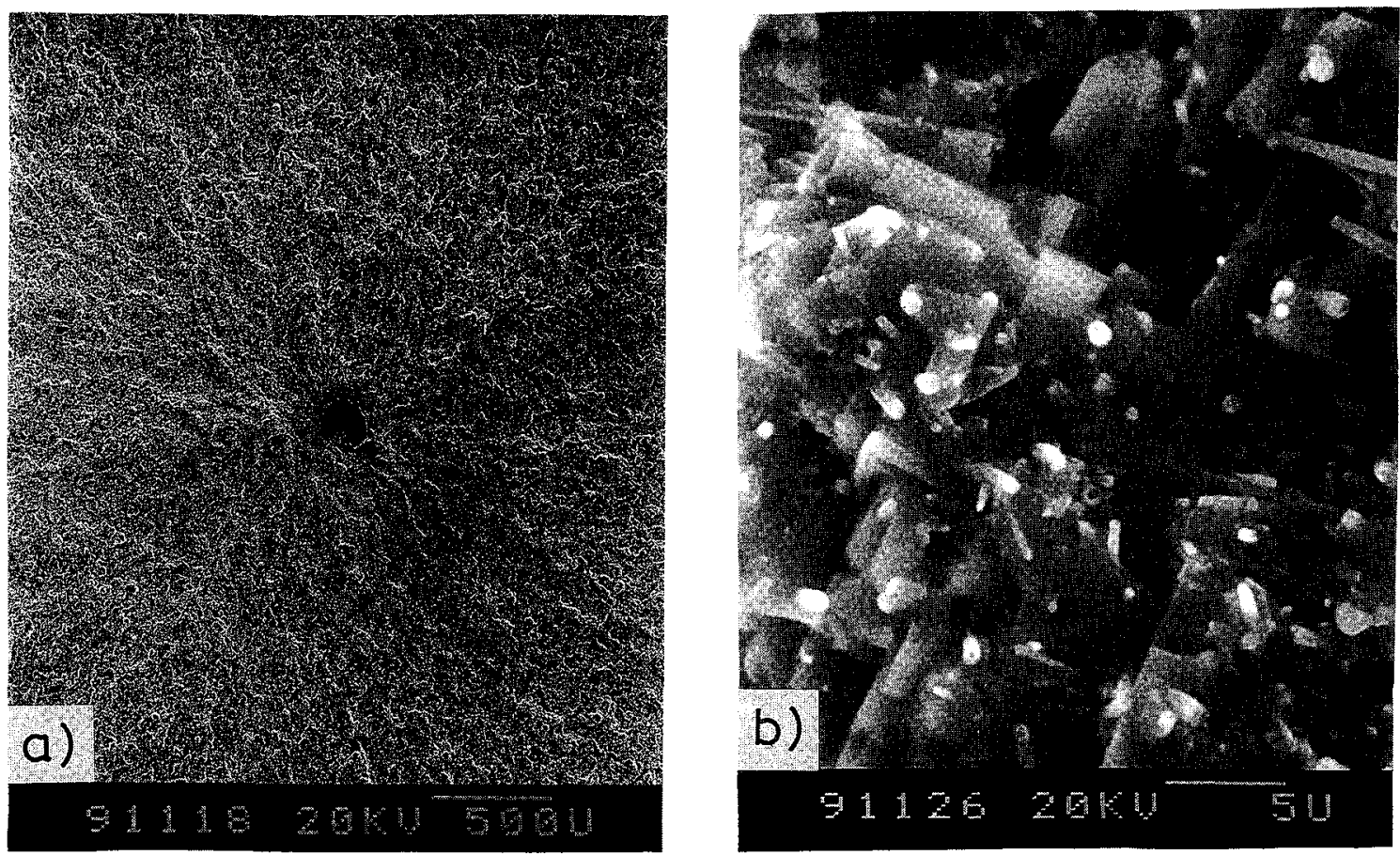

Fig. 9 (a) Typical fatigue crack initiation from a defect in the $\mathrm{SiC}_{\mathrm{w}} / 7075-\mathrm{T} 6 \mathrm{Al}$ composite and (b) Inside of the defect. $\sigma_{\mathrm{a}}$ $=160 \mathrm{MPa}, N_{\mathrm{f}}=6.32 \times 10^{6}$. 


\section{(1) 摩擦係数}

フレッティング疲労破壞に関与する応力振幅は $\sigma_{\mathrm{a}}$ と $2 f_{\mathrm{a}}$ で ある(13).

$$
f_{\mathrm{a}}=\mu p
$$

ここで $f_{\mathrm{a}}$ は摩擦力振輻， $\mu$ は摩擦保数， $p$ はパッド接触面圧で ある。 $f_{\mathrm{a}}$ は $\mu$ が小さい汪ど小さいので，フレッティング疲労 強度は $\mu$ が小さいほど高くなる， $\mu$ は接触する材料の種類(14) や環境(7)の影響を受ける。

複合材料执よび非強化材料の $\mu$ を測定した結果を Fig. 10 K 示す， $\mu$ は両試料間でほぼ同じである。したがって本試験で は， $\mathrm{SiC}_{\mathrm{w}}$ は摩擦力低下によるフレッティング疲労強度向上に 奇与していない。

な执，Al 合金を $\mathrm{SiC}$ 粒子で複合化することにより，似低

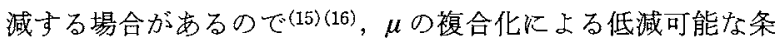
件を明確にすることが必要である。

\section{(2) パッド接触部の主き裂発生位置}

試驗片とパッドの接触部は stick regionとその両側にある slip regionから構成されて和り，き裂忹兩 regionの境界で発 生する。模式図をFig.11亿示す，押付け力が大きいと stick regionの面積は広くなり，き裂はパッド接触端部近くで発生 する。このような場合，摩擦力は押付け力とともに增大するの で，寿命は押付け力とともに減少する。しかし押付け力が比較 的小さい場合， stick regionが著しく狭くなり，その結果き裂

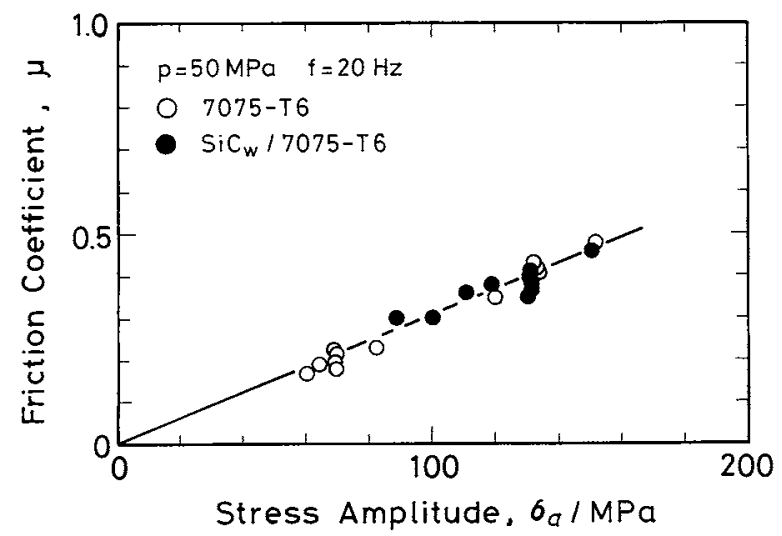

Fig. 10 Friction coefficient as a function of stress amplitude.

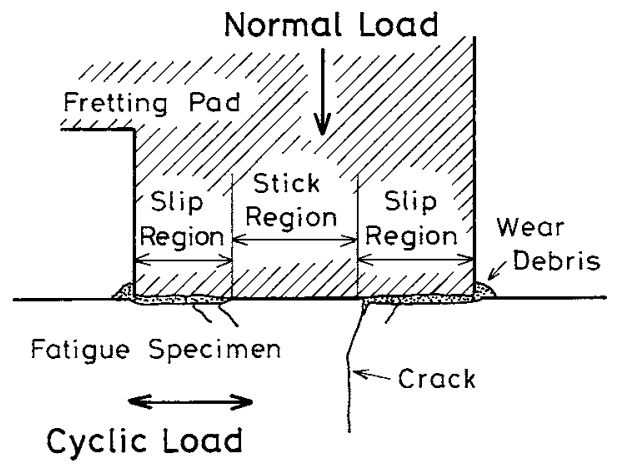

Fig. 11 Schematic representation of fretting damage on the contact area.
はパッド接触部の中央近くから発生し, 破断寿命は短く, 破断 強度は低くなる。それはパッドを通しての押付け力が stick region に集中するためと考劣られる(17).

III.2で述べたように全般に非強化材料ではき裂はパッド接 触部中央，すなわち狭いstick region下で発生していた。一 方，複合材料の場合，き裂は全般に接触部端部から発生してい た。したがってパッド接触面の挙動は非強化材料のフレッティ ング疲労強度に不利炸用している。このき裂発生位置の違い は，高張力鋼および Ti-6A1-4V 合金の場合，高サイクル側で $20 \sim 30 \mathrm{MPa} の$ 強度差となっている(17).この類推から, 複合 材料と非強化材料のフンッティング疲労強度の差のうち20 $30 \mathrm{MPa}$ はパッド接触部の主き裂発生位置の違いに起因してい ると考觉られる。

\section{(3) 摩耗による初期微小き裂の研削}

パッドによる試験片の摩耗はフレッティング疲労寿命を延命

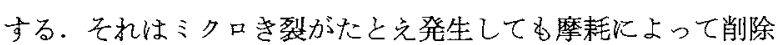
されるために，伝播可能なき裂長さに達するまでの絽返し数が 大さくなるからである(7)。しかし本研究で使用した複合材料㧍 よび非強化材料はともに摩耗は極微量であるので，(3)の効果は ない。

\section{(4) $\mathrm{SiC}_{\mathrm{w}}$ のき裂発生への影響}

フレッティング疲労に括いては，通常の疲労と異なり，き裂 発生特よび初期き裂伝播域では押付け力括よび摩擦力の影響を 受ける，き裂は摩擦力の影響をら汁て㑯いて発生し，通常の疲 労より速い速度で進展し，き裂長さとともに速度は遅くなる。 そして極小値を示した後，き裂はその長さとともに速くなり， そして破断する。

Fig. 4(a)および(b)に示したよらに，両試料と耐久限度に 近い応力振幅下ではフレッティング損傷が飽和するのは全寿命 の90\%以上に扎いてである。この飽和はき姴伝播速度が極小 值を示す付近で生でるので(18)，き裂伝播寿命の全寿命に対す る割合は $20 \%$ 以下である。全寿命の大半はき裂発生に費やさ れている.Fig. 3 亿示した複合材料の実測 S-N 曲線が，推定 $\mathrm{S}-\mathrm{N}$ 曲線より，特に高サイクル側で著しく長寿命側にくるの は, $\mathrm{SiC}_{\mathrm{w}}$ 複合化によるき裂発生の遅延が寄与している可能性 が济る。

$\sigma_{\mathrm{B}}$ が一定の場合, 疲労強度 $\sigma_{\mathrm{w}}$ は結晶粒径が小さい汪ど高 い、それはき裂発生を制御するからである(19). Fig. 12(a)K 示すように $\mathrm{SiC}_{\mathrm{w}}$ が細粒化と同じ効果を発揮する.非強化材料 の平均粒径は数 $\mu \mathrm{m}$ である、これに比べて Fig. 1 ( $\mathrm{T}$ 方向)に示 したように複合材料の $\mathrm{SiC}_{\mathrm{w}}$ の平均自由距離は土はるか小さ W.

式( 3 )の $\sigma_{\mathrm{w}, \mathrm{M}}$ と $\sigma_{\mathrm{B}, \mathrm{M}}$ との関係に影響をおよぼす因子とし $\tau$, 上述の結晶粒径以外飞, 繰返し硬化・軟化挙動がある ${ }^{(19)}$. $\sigma_{\mathrm{w}, \mathrm{M}}$ は繰返乙軟化の場合，繰返し硬化の場合に比べて低くな る。本実験で用いた T6 処理のよらな繰返し軟化するマトリッ クスを $\mathrm{SiC}_{\mathrm{w}}$ で強化すると繰返し軟化の度合いが抑制され，そ の結果フレッティング疲労強度は増加する。

さらにFig. 12(b)飞示す上5に，発生した初期微小き裂先端 の繰返し応力下に持ける拡大が $\mathrm{SiC}_{\mathrm{w}}$ に上り抑制される効果も フレッティング疲労強度を増加させる。 


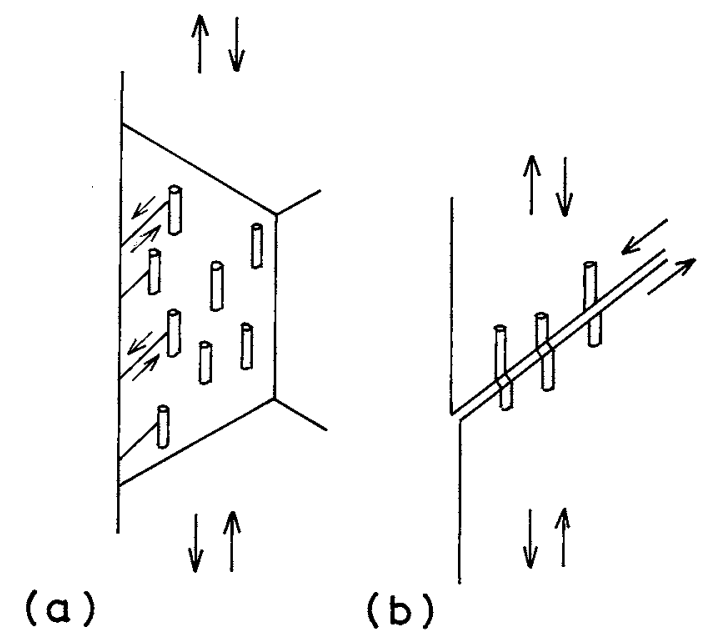

Fig. 12 Schematic representation of the mechanisms of reinforcement on fatigue crack initiation.
(a) Barrier against slip.
(b) Barrier against crack initiation.

\section{(5) $\mathrm{SiC}_{\mathrm{w}}$ のき裂伝播への影響}

$\mathrm{SiC}_{\mathrm{w}} / 7075-\mathrm{T} 6$ の $\mathrm{d} a / \mathrm{d} N$ は低広力拡大係数域で, 7075-T6 $\mathrm{d} a / \mathrm{d} N$ 上りやや速く, $\mathrm{SiC}_{\mathrm{w}}$ 複合化に上るき裂伀播抑制効果 は現れていない(20).しかし $\mathrm{SiC}_{\mathrm{w}}$ による複合化でもマトリッ クスの種類によっては $\mathrm{d} a / \mathrm{d} N$ は遅延する. $\mathrm{SiC}_{\mathrm{w}} / 2025-\mathrm{T} 6$ が その例である(16)。前述したよらに両材料とる高サイクル域で は寿命の大半はき裂発生寿命であるので，き裂伝播過程の挙動 はこの両材料ではそれほど重要ではない。

大部分の金属材料化括いて，フレッティング損傷が飽和する のは，耐久限度近い応力レベルでは全寿命の30 50\%であ る(21)。これは本実験で使用した非強化材料和よび複合材料と は著しく異なる点である．用いた村料は相対的にき裂云播が容 易な材料であることを意味している.

以上の考察より $\mathrm{SiC}_{\mathrm{w}} / 7075-\mathrm{T} 6$ 合金の高サイクル側のフレッ ティング疲労強度が， $\mathrm{SiC}_{\mathrm{w}}$ 複合化による $E$ と $\sigma_{\mathrm{B}}$ の増加分を 考慮したフレッティング疲労強度推定值より高いのは, 複合化 によりパッド接触面における椇傷形態が変化をうけ，沈力集中 が分散されるため执よび，き裂発生が㧕制されるためであると 結論できる。

\section{V. 結 論}

(1) $10^{7}$ 回フレッティング疲労強度は $\mathrm{SiC}_{\mathrm{w}} / 7075-\mathrm{T} 6$ 合金で

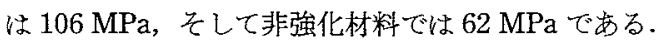

（2） $10^{7}$ 回通常疲労強度は複合材料，非强化材料ともに約 $155 \mathrm{MPa}$ である.

（3）複合材料および非強化材料はとるにフレッティング疲労 寿命の $80 \%$ 以上はき裂発生㵒やされる.

(4) 摩擦係数は複合材料と非強化材料で添济同じである。

（5）主さ裂発生個所は，複合材料ではパッド接触部端部，そ して非強化材料ではパッド接触部中央部である。
（6）複合化による疲労乱よびフレッティング疲労強度向上に ついて，(a)複合化に伴らヤング率の变化を考慮した引張強さの 増加あるい墭少の寄与分之(b)強化相に上る強化機構発現によ る寄与分に分けて評価する方法を提起した。(b)の寄与分が正の 場合，金属マトリックス自体の疲労技よびフレッティング疲労 強度を高める機構が複合化炕より発現している。

(7) (6)に基づいて, $\mathrm{SiC}_{\mathrm{w}} / 7075-\mathrm{T} 6$ 合金の $10^{7}$ 回フレッティ ング疲労強度を評価した結果，複合化火より約 $44 \mathrm{MPa}(70 \%)$

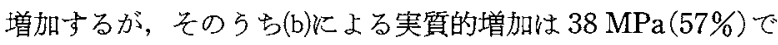
ある。この寒質増加は，複合材料に扣いてはパッド接触面の stick region が広くなるために応力集中の度合いが低いこと特 上び $\mathrm{SiC}_{\mathrm{w}}$ による細䊀化効果抢よび徽小き裂閉口効果のために き裂発生が抑制されることが原因しているためと考えられる。

(8) 複合材料の $10^{7}$ 回通常疲労強度の実測值と(6)の(a) 江よる 推定值はほ洼同じ水準である。複合材料に执いてき裂は大きさ 150〜200 $\mu \mathrm{m}$ の内部にる欠陷から発生している.

有益な討諭をしていただいた金属材料技術研究所，中村森彦 博士に感謝する。

\section{文献}

（1）例光ば，J. K. Shang, W. -K. Yu and R. O. Ritchie: Mater. Sci. Eng. A, 102(1988), 181.

(2) P. R. Gibson, A. J. Clegg and A. A. Das: Wear, 95 (1984), 193.

（3）野吕瀬 進, 䈎田 直, 宮下忠志: トライボロジスト, $\mathbf{3 4}(1989), 538$.

(4) J. J. Bonnen, J. E. Allison and J. W. Jones: Met. Trans, A, 22A (1991), 1007.

（5）中沢興三, 角田方葦, 丸山典夫, 河部義邦: 鉄と鍋, 74 (1988), 725 .

（6）金属材料疲労設計便覧，日本材料学会編(㙞賢堂), (1978), 4 .

（7）丸山典夫, 角田方衛, 中沢與三：鉄と鋼，77(1991), 290.

（8）中沢與三，角田方衛，丸山典夫：鉄と鋼，76(1990), 1552.

(9) M. Sumita, I. Uchiyama and T. Araki: Trans. ISIJ, $14(1974), 275$

（10）村上敬宣：鉄之鋼， 75(1989), 1267 .

（11）増田千利, 田中義久：鉄と鋼, 75 (1989), 1753 .

（12）服部 武, 酒井茂男：三菱重工技報, 25 (1988)，357.

(13) 西岡邦夫, 平川賢爾: 日本機械学会論文集(第 1 部), $37(1971), 1051$.

(14) 条村好次：鉄之鋼， 72(1986)，1231.

(15) Farid Rana and D. M. Stefanescu: Met. Trans., 20A (1989), 1564

(16) A. Wang and H. J. Rack: Mat. Sci. \& Eng., A147 (1991), 211.

(17) N. Nakazawa, M. Sumita and N. Maruyama: ASTM STP $1159,(1992), 115$.

（18）角田方衛，中沢興三：「腐食損傷を受ける鉄鋼の寿命 · 余寿命評侕 $、=7 ル$ 日本鉄鋼拹会, 特定基礎研究 会, 構造材料の信賴性評価技術部会, (1991), 243.

（19）角田方衛，内山 郁：鉄と鋼，63(1977), 1700.

(20) K. Hirano: Fatigue 90, Proceedings of the 4th International Conference on Fatigue and Fatigue Thresholds, Materials and Component Engineering Publications Ltd, UK, (1990), 863 .

（21）佐藤建吉, 出口伸幸 : 日本材料強度学会誌, 22(1987), 94. 